\title{
The Influence of Turnover Factors Toward Employees' Intention to Stay: A Case Study in Indonesian Islamic Universities
}

\author{
Nazaruddin Malik \\ Department of Economic Development, University of Muhammadiyah Malang, Indonesia \\ Jl. Tlogomas No. 246 Tlogomas, Malang, East Java 65144, Indonesia \\ Corresponding author: nazaruddin@umm.ac.id
}

\section{ARTICLE INFO}

Article history

Received December 12, 2019 Revised February 29, 2020 Accepted February 29, 2020 Available Online February 29, 2020

Keywords

Religiosity

Job satisfaction

Organizational commitment

Intention to stay

Employee turnover

\begin{abstract}
This study analyzed employee turnover factors, such as satisfaction, organizational commitment, and religiosity, to predict the employees' intention to stay. Very few studies in the Muslim context have explored such a corporate attitude from job satisfaction and organizational commitment. This study employed a quantitative and descriptive research design. A survey was used to analyze the correlation between some predictors of the employees' intention to stay. In particular, it attempted to show that religiosity affected both job satisfaction and organizational commitment either directly or indirectly. The data were obtained from 150 employees in some Islamic universities in Malang, Indonesia. The findings revealed that religious beliefs influenced job satisfaction. Job satisfaction significantly affected the employees' commitment. Religiosity directly impacted corporate commitment through job satisfaction, and religiosity was positively related to the employees' intention to stay. Regarding this, the employees who keep religious beliefs in the workplace are encouraged to perform excellently.
\end{abstract}

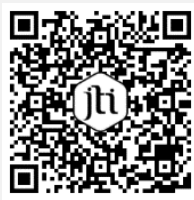

This is an open-access article under the CC-BY-SA license.

\section{Introduction}

Human resource management broadly discusses several complex issues in an organization [1]. One of the complex problems is employee turnover. It is defined as the rotation of many employees who leave or are replaced in an organization [2]. A high turnover rate in human resource management is considered a severe issue. First, a high turnover rate may lead to financial consequences. The more employees leave, the more additional costs to recruit, select, and train new employees [3]. Second, it may slow down the company's productivity and performance. Moreover, employees who have a crucial position apparently, take an essential role in the organization. If the organization fails to overcome the turnover problems, the organization will find it hard to compete [4]. Therefore, the organization needs to identify and understand the factors contributing to employee turnover. 
Some previous studies examined religiosity as a factor that triggers employees to stay. King and Williamson [5] studied the relationship between workplace religious expression, religiosity, and job satisfaction. Kutcher, et al. [6] investigated The role of religiosity in stress, job attitudes, and organizational citizenship behavior. Wening and Choerudin [7] studied the influence of religiosity on organizational commitment, job satisfaction, and personal performance. Organizational commitment has also attracted many researchers. According to Williams and Hazer [8] and Cohen [9], organizational commitment still serves as immediate attention. It may be a good employee turnover policy. Moreover, Bouarif [10] and Sikorska-Simmons [11] investigated organizational commitment and ethical ideology. It has several dimensions of theological such as dogma, rituals, and formality [12].

Several factors are affecting the level of job satisfaction [13]. Frye [14] summarized that compensation is positively correlated with job satisfaction. A study on factors affecting employee job satisfaction was conducted by Parvin and Kabir [15]. The result showed that a relationship among co-workers becomes the essential factor. Furthermore, satisfied employees are more likely to show better job performance [16]. Gersten, et al. [17] studied factors that enhance special educators' intention to stay in the organization. The factors that influence employees' intention to stay or leave were also investigated by Lee and Chao [18] and Alausa Waheed, et al. [19].

A significant variable influencing employee turnover is job satisfaction [20]. The impact of job satisfaction on employee turnover was studied by Khan and Aleem [21]. A previous study examined the influence of employees' religiosity on their turnover intention [22]. This study found that intrinsic religiosity is negatively related to turnover intention, and extrinsic religiosity is positively related to turnover intention. Malik et al. [23] researched one faculty of a university. They found that dimensions of religiosity positively impact organizational commitment.

The previous studies revealed that several studies had addressed the relationship between the turnover factors and the employees' intention to stay. However, research on turnover factors to predict employees' intention to stay is still limited. Therefore, this study aims to analyze the turnover factors influencing the intention to stay. This research employs some turnover factors such as religiosity, job satisfaction, and organizational commitment. The contribution of this study is to determine whether or not the turnover factors influence the employees' intention to stay in Indonesian Islamic universities.

\section{Methods}

\subsection{Conceptual Framework and Research Hypotheses}

\subsubsection{Research Conceptual Framework}

The conceptual framework is described in Fig. 1. Four variables were used in the research: religiosity, job satisfaction, organizational commitment, and intention to stay. Ten hypotheses were used in this research. These are explained in the following subsection.

\subsubsection{Research Hypotheses}

Ten hypotheses are presented as follows:

Hypotheses 1 : Religiosity influences the employees' intention to stay in Islamic Universities in Malang, East Java, Indonesia

Hypotheses 2 : Religiosity influences the employees' job satisfaction in Islamic Universities in Malang, East Java, Indonesia 
Hypotheses 3 : Religiosity influences the employees' organizational commitment in Islamic Universities in Malang, East Java, Indonesia

Hypotheses 4 : Job satisfaction influences the employees' intention to stay in Islamic Universities in Malang, East Java, Indonesia

Hypotheses 5 : Job satisfaction influences the employees' organizational commitment in Islamic Universities in Malang, East Java, Indonesia

Hypotheses 6 : Corporate commitment influences the employees' intention to stay in Islamic Universities in Malang, East Java, Indonesia

Hypotheses 7 : Religiosity influences the employees' intention to stay through job satisfaction in Islamic Universities in Malang, East Java, Indonesia

Hypotheses 8 : Religiosity influences the employees' intention to stay through job satisfaction and organizational commitment in Islamic Universities in Malang, East Java, Indonesia

Hypotheses 9 : Religiosity influences the employees' intention to stay through organizational commitment in Islamic Universities in Malang, East Java, Indonesia

Hypotheses 10 : Religiosity influences the employees' organizational commitment through job satisfaction in Islamic Universities in Malang, East Java, Indonesia

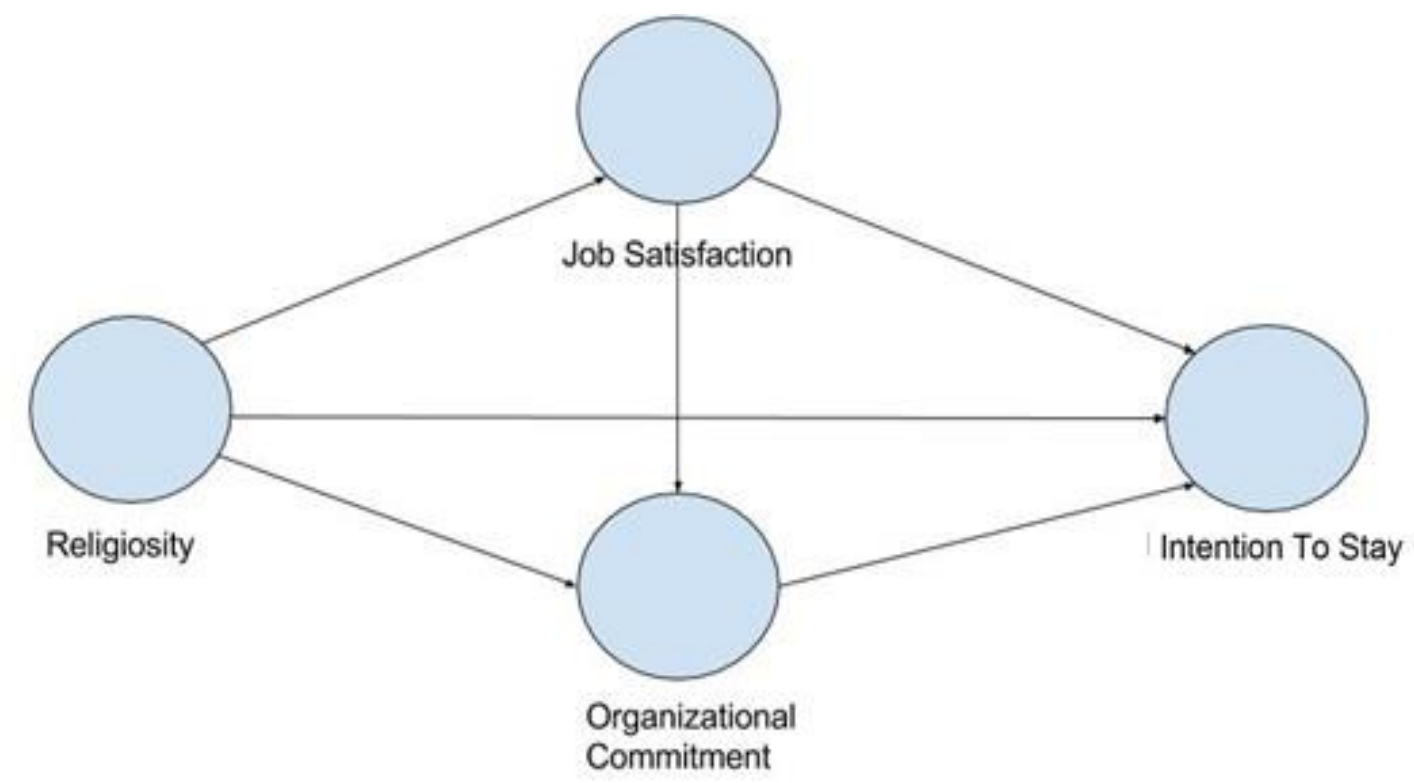

Fig. 1. The Conceptual Framework

Hypotheses 1 was based on the research by Hassan, et al. [24]. They used three dimensions of religiosity, such as (1) policy and procedure, (2) leadership style, and (3) religious calling. The study showed that religious calling does not have any significant influence on turnover intention. Hypothesis 2 was based on Milliman et al. [25]. They found that religiosity and job satisfaction constitutes a strong correlation. They believed that religiosity affects job satisfaction directly. However, religiosity can also be a replacement for job satisfaction under certain circumstances [26].

In the third hypothesis, religiosity affects organizational commitment. It was based on Salem and Agil [27]. Kudo, et al. [28] revealed that motivational factors significantly influence the intention to stay. Moreover, job satisfaction influences employees' intentions 
to stay. Hence, in the fourth hypothesis, job satisfaction influences the employees' intention to stay in Islamic Universities. Azeem [29] investigated the relationships among demographic factors, job satisfaction, and organizational commitment. The result of the study showed that age and job tenure significantly affect organizational commitment. Therefore, in the fifth hypothesis, job satisfaction affects organizational commitment.

In the sixth hypothesis, organizational commitment affects the employees' intention to stay in Islamic Universities. Employee's organizational commitment is triggered by the sense of belonging to the organization and concern for the company's future. The seventh hypothesis is that religiosity influences the employees' intention to stay through job satisfaction in Islamic Universities. It was based on Zafar, et al. [30]. They found the impact of religiosity on the intention to stay in banking sector employees. The result revealed religiosity as a factor that affects the employees' decision to either switch or quit from the banking sector. Therefore, religiosity influences the employees' intention to stay.

The eight hypotheses are that religiosity influences the employees' intention to stay through job satisfaction and organizational commitment in Islamic Universities. The direct impacts of Islamic work ethics are organizational commitment and job satisfaction. In other words, Islamic work ethics affect organizational commitment and job satisfaction. The ninth hypothesis is that religiosity influences the employees' intention to stay through organizational commitment. The workers with a high level of religiosity perform different behavior in the workplace. They create a pleasant environment in the workplace. The last hypothesis is that religiosity influences organizational commitment through job satisfaction. In religiosity and organizational commitment, the Islamic work atmosphere directly influences organizational commitment and job satisfaction.

\subsection{Data Collection}

This research used a quantitative descriptive research design. A survey was employed in the data collection. The questionnaire in the survey was divided into parts, namely (1) religiosity in a workplace, consisting of four questions, 2) job satisfaction, consisting of six questions, 3) organizational commitment, consisting of four questions, and 4) intention to stay, consisting of two questions. The indicators of the variables are shown in Table 1. The questionnaire used a Likert Scale ranging from 1 "strongly disagree" to 7 "strongly agree." The number of the population of this research was 150 respondents, from employees (lecturers and staff) of several Islamic universities in Malang, Indonesia.

\subsection{Data Analysis}

The test used convergent validity; The evaluation was committed using the square root of Average Variance Extracted (AVE), Evaluation on Composite Reliability, R-Square, and Hypothesis Testing. The technique of data analysis was a descriptive and inferential statistics technique, using the Smart PLS software. Convergent validity is a test to measure the validity of reflective indicators as the variables. An indicator is categorized right if the value of the outer loading is above 0.70 . the loading value above 0.5 is still considered.

The research model has a good discriminant validity in discriminant validity if the AVE value is more significant than 0.5. In the Evaluation on Composite Reliability, the Latent variable has good reliability if the composite reliability is more than 0.70 (0.5 is still considered normal) [31]. The high score of composite reliability indicates the internal 
consistency of each indicator in measuring the construction. Cronbach's alpha score $>0.60$ shows the construction has good reliability. R-Square test is used to measure the influence of exogenous latent variables on the endogenous latent variables. Moreover, Hypothesis Testing was carried out to test the hypotheses.

Table 1. Indicator of Variables

\begin{tabular}{|c|c|c|}
\hline No & Variables & Indicators \\
\hline \multirow[t]{4}{*}{1} & Religiosity & R7 (religious persistence) \\
\hline & & R8 (opportunity to doing good deeds) \\
\hline & & R9 (activity to improve religious quality) \\
\hline & & R10 (harmony between vision and mission of the \\
\hline \multirow[t]{6}{*}{2} & Job Satisfaction & JS1 (suitability of work placement) \\
\hline & & JS2 (enjoyment of work) \\
\hline & & JS5 (suitability of rights and obligations) \\
\hline & & JS6 (work appreciation from the institution) \\
\hline & & JS7 (promotion based on performance) \\
\hline & & JS9 (excellent communication with leaders) \\
\hline \multirow[t]{4}{*}{3} & Organizational & OC1 (willingness to work overtime) \\
\hline & & $\begin{array}{l}\text { OC3 (institutional problems are also employee } \\
\text { problems) }\end{array}$ \\
\hline & & OC4 (work loyalty) \\
\hline & & OC5 (pride in the workplace) \\
\hline \multirow[t]{2}{*}{4} & Intention to Stay & IL1 (intention to stay) \\
\hline & & $\begin{array}{l}\text { IL4 (compatibility of the personal work plan with } \\
\text { the institution) }\end{array}$ \\
\hline
\end{tabular}

\section{Results and Discussion}

\subsection{The Results of Validity and Reliability Tests}

\subsubsection{The Results of Convergent Validity}

The result of the convergent validity test of the variable religiosity, job satisfaction, organizational commitment, and intention to stay at Islamic University is presented in Table 2. The results show that all indicators were valid.

\subsubsection{Evaluation of Discriminant Validity}

The evaluation was conducted using the square root of Average Variance Extracted (AVE) and composite reliability values. The results of the average variance extracted (AVE) are presented in Table 3. It shows that AVE scores were above 0.50. It means that the model of the research had a good discriminant validity.

\subsubsection{Evaluation of Composite Reliability}

The results of the reliability test are presented in Table 4. The score of the composite reliability for the organizational commitment variable was 0.851 ; the job satisfaction variable was 0.819 . Moreover, the score of the composite reliability for religiosity and intention to stay variables were 0.711 and 0.629 , respectively. Table 4 also shows that all variables in this research had Cronbach's alpha score $>0.60$, indicating that the constructions had good reliability. 
Table 2. Convergent Validity Results

\begin{tabular}{|c|c|c|c|c|}
\hline No & Variables & Indicators & Outer Loadings & Results \\
\hline \multirow[t]{4}{*}{1} & \multirow[t]{4}{*}{ Religiosity } & $\mathrm{R} 7$ & 0.579 & Valid \\
\hline & & $\mathrm{R} 8$ & 0.541 & Valid \\
\hline & & R9 & 0.736 & Valid \\
\hline & & $\mathrm{R} 10$ & 0.605 & Valid \\
\hline \multirow[t]{6}{*}{2} & \multirow[t]{6}{*}{ Job Satisfaction } & JS1 & 0.582 & Valid \\
\hline & & JS2 & 0.609 & Valid \\
\hline & & JS5 & 0.696 & Valid \\
\hline & & JS6 & 0.676 & Valid \\
\hline & & JS7 & 0.739 & Valid \\
\hline & & JS9 & 0.623 & Valid \\
\hline \multirow[t]{4}{*}{3} & \multirow[t]{4}{*}{$\begin{array}{l}\text { Organizational } \\
\text { Commitment }\end{array}$} & OC1 & 0.730 & Valid \\
\hline & & OC3 & 0.757 & Valid \\
\hline & & $\mathrm{OC} 4$ & 0.780 & Valid \\
\hline & & OC5 & 0.800 & Valid \\
\hline \multirow[t]{2}{*}{4} & \multirow[t]{2}{*}{ Intention to Stay } & IL1 & 0.696 & Valid \\
\hline & & IL4 & 0.658 & Valid \\
\hline
\end{tabular}

Table 3. AVE Results

\begin{tabular}{cll}
\hline No & \multicolumn{1}{c}{ Variables } & AVE \\
\hline 1 & Religiosity & 0.882 \\
2 & Job Satisfaction & 0.785 \\
3 & Organizational Commitment & 0.500 \\
4 & Intention to Stay & 0.678 \\
\hline
\end{tabular}

Table 4. Composite Reliability Results

$\begin{array}{clcc}\text { No } & \text { Variables } & \text { Composite Reliability } & \text { Cronbach Alpha } \\ 1 & \text { Religiosity } & 0.711 & 0.711 \\ 2 & \text { Job Satisfaction } & 0.819 & 0.816 \\ 3 & \text { Organizational Commitment } & 0.851 & 0.852 \\ 4 & \text { Intention to Stay } & 0.629 & 0.629\end{array}$

\subsection{The Results of Model}

R-Square score analysis is presented in Table 5. It shows that the score for the job satisfaction variable was $88.5 \%$. The religiosity variable explains that the variant of the job satisfaction variable reached $88.5 \%$. Meanwhile, the score of the organizational commitment variable was $80.1 \%$. It means that there is a strong correlation between religiosity, job satisfaction, and organizational commitment to some Islamic Universities. 
The dependent variable of intention to stay was 56.1\%. It shows that religiosity, job satisfaction, and organizational commitment variables were able to define the variants of intention to stay variable by $56.1 \%$. At the same time, the rest was not attached in this research. In short, this correlation is considered moderate.

Table 5. R-Square Scores Analysis

\begin{tabular}{lll}
\hline No & Variables & R-Square \\
\hline 1 & Job Satisfaction & 0.885 \\
2 & Organizational Commitment & 0.801 \\
3 & Intention to Stay & 0.561 \\
\hline
\end{tabular}

\subsection{Hypothesis Testing}

The findings of the loading factor of religiosity, job satisfaction, organizational commitment, and intention to stay are shown in Fig. 1. The results of the hypothesis test are presented in Table 6 and Table 7.

Table 6. Hypotheses of Direct Influence

\begin{tabular}{|c|c|c|c|c|}
\hline No & Types of Correlation & Path Coefficient & t-stat & P-Value \\
\hline 1 & $\begin{array}{l}\text { Religiosity on intention to } \\
\text { stay }\end{array}$ & $1.303^{* *}$ & 1.627 & 0.104 \\
\hline 2 & Religiosity on job satisfaction & $0.941^{*}$ & 11.372 & 0.000 \\
\hline 3 & $\begin{array}{l}\text { Religiosity on organizational } \\
\text { commitment }\end{array}$ & 0.673 & 0.389 & 0.697 \\
\hline 4 & $\begin{array}{l}\text { Job satisfaction on intention } \\
\text { to stay }\end{array}$ & 0.493 & 0.966 & 0.335 \\
\hline 5 & $\begin{array}{l}\text { Job satisfaction on } \\
\text { organizational commitment }\end{array}$ & $1.346^{*}$ & 3.521 & 0.000 \\
\hline 6 & $\begin{array}{l}\text { Organizational commitment } \\
\text { on the intention to stay }\end{array}$ & 0.076 & 0.132 & 0.895 \\
\hline
\end{tabular}

Note: *significant to a $5 \%, * *$ significant to a $20 \%$

The first hypothesis was that religiosity influenced intention to stay. Based on the test, religiosity did influence the intention to stay. It means that the employees show a higher level of religiosity, the stronger intention to stay. The P-value of 0.104 was significant in a $20 \%$. It means that religiosity positively influences the intention to stay. The second hypothesis examined the direct influence of religiosity on job satisfaction. The result shows that path coefficient and t-statistic were 0.941 and 11.372 , respectively ( $\mathrm{p}$ value $=0.000$ ). It indicates that religiosity affects job satisfaction. The higher the level of religiosity, the stronger job satisfaction will be. The P-value of 0.000 significance was in a $5 \%$. It shows that religiosity significantly influences the intention to stay.

The third hypothesis examined the direct influence of religiosity on organizational commitment. The test shows that path coefficient and t-statistic were 0.673 and 0.389 , respectively $(p$-value $=0.697)$. It indicates that religiosity influences organizational commitment. In other words, the higher level of religiosity, the stronger organizational commitment will be. However, It is not significant. The fourth hypothesis examined the direct influence of job satisfaction on intention to stay. Based on the test, the path 
coefficient and t-statistic were 0.493 and 0.966 respectively $(p$-value $=0.335)$. It indicates that job satisfaction influences intention to stay. However, it is not significant.

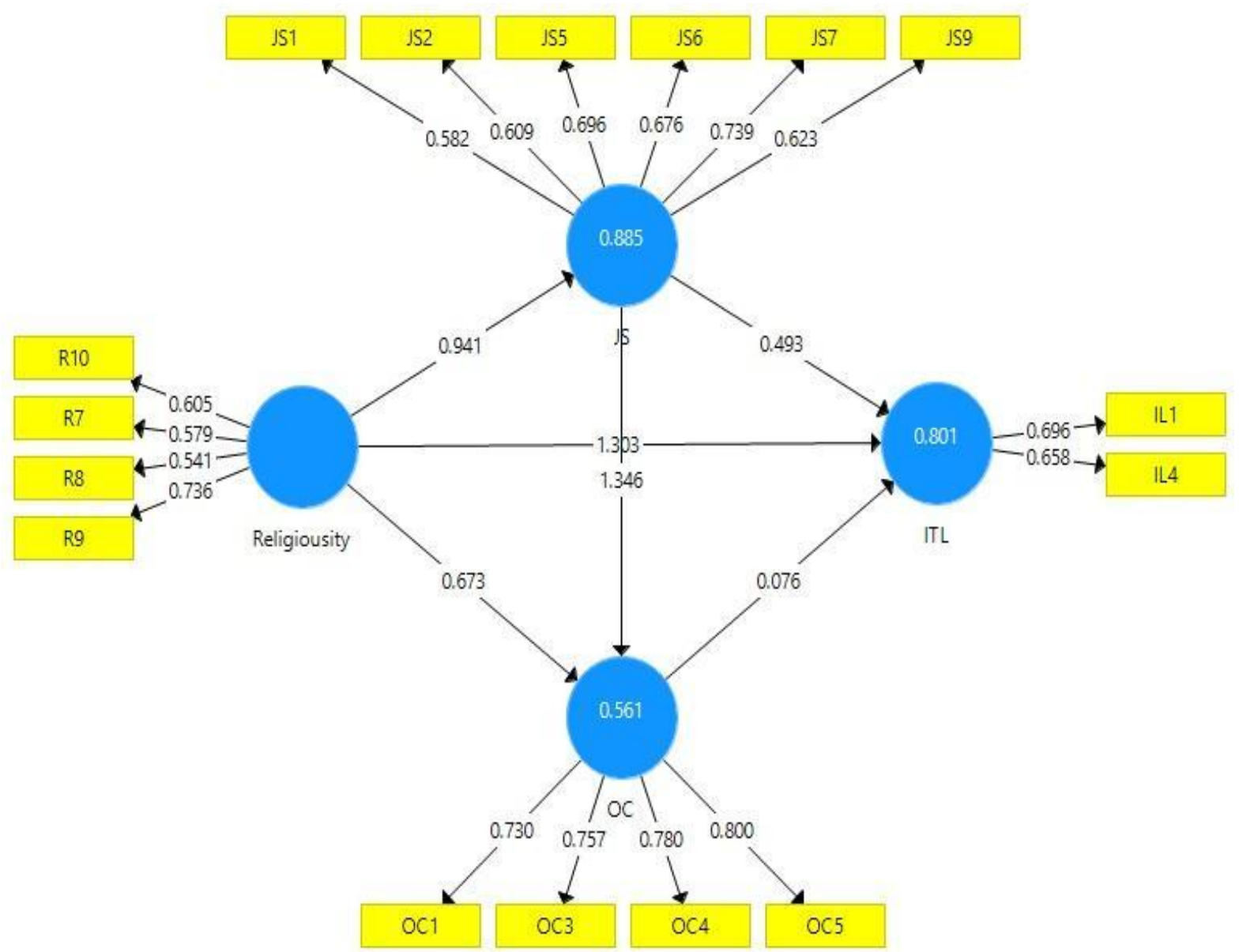

Fig. 2. Loading Factor Variables from PLS

The fifth hypothesis examined the direct influence of job satisfaction on organizational commitment. The path coefficient and t-statistic were 1.346 and 3.521 respectively $(p$-value $=0.000)$. It indicates the job satisfaction influenced organizational commitment. P-value of 0.000 was significant in a 5\%. It shows that job satisfaction significantly influenced organizational commitment. The sixth hypothesis examined the direct influence of organizational commitment on the intention to stay. The path coefficient and t-statistic were 0.076 and 0.132 , respectively ( $\mathrm{p}$-value $=0.895$ ). It indicates that the influence of organizational commitment on the intention to stay is directly proportional. However, it is not significant.

The seventh hypothesis examined the indirect influence of religiosity on the intention to stay through job satisfaction. The path coefficient and p-value were 0.464 and 0.364 , respectively. It indicates that the impact of religiosity on the intention to stay through job satisfaction is directly proportional. However, it is not significant. The eighth hypothesis examined the indirect influence of religiosity on staying through job satisfaction and organizational commitment. The positive path coefficient of 0.096 indicated the influence of religiosity on staying through job satisfaction. Organizational commitment is directly proportional. However, the P-value of 0.899 shows that it is not significant. 
Table 7. Indirect Influence Test

\begin{tabular}{llll}
\hline No & Correlation Path & Coefficient & P-Value \\
\hline 1 & $\begin{array}{l}\text { Religiosity on intention to stay through job } \\
\text { satisfaction }\end{array}$ & 0.464 & 0.346 \\
2 & $\begin{array}{l}\text { Religiosity on the intention to stay through job } \\
\text { satisfaction and organizational commitment }\end{array}$ & 0.096 & 0.899 \\
3 & $\begin{array}{l}\text { Religiosity on the intention to stay through } \\
\text { organizational commitment } \\
\text { Religiosity on organizational commitment through job } \\
\text { satisfaction }\end{array}$ & 0.051 & 0.966 \\
\hline
\end{tabular}

Note: *significant to a $5 \%$

The ninth hypothesis examined the indirect influence of religiosity on the intention to stay through organizational commitment. A positive path coefficient of 0.051 indicates that the influence of religiosity on the intention to stay through organizational commitment is directly proportional. However, the P-value of 0.966 shows that it is not significant. The tenth hypothesis examined the indirect influence of religiosity on organizational commitment through job satisfaction. Based on the test, the path coefficient and $p$-value were 1.267 and 0.001 , respectively. It indicates that the influence of religiosity on organizational commitment through job satisfaction is directly proportional. P-value was of 0.001 means significant in a $5 \%$. It indicates that religiosity positively influences organizational commitment through job satisfaction.

\subsection{Discussion}

This research shows that religiosity has a significant and positive relationship with the intention to stay, either directly or indirectly. Moreover, some hypotheses of direct religiosity affect other variables with highly significant relations, as follows: 1 ) religiosity to intention to stay ( ${ }^{*}$ significant to a $20 \%$ ). From the research findings, the relationship between religiosity to stay is substantial and positive. However, among the five items of intention to stay variables, the only one item with high validity is only item 1 (I will stick with my current job) and 4 (I have a long-term work plan, and my institution is now always in the plan), 2) religiosity to job satisfaction (*significant to a $5 \%$ ), and 3) job satisfaction toward organizational commitment (* significant to a $5 \%$ ). It can be argued that the higher the religiosity of the employee, the greater their intention to stay will be. It can be seen from the demographic data of the respondents who have an average working period of more than 25 years. Therefore, they have more time to understand profoundly and have a sense of self-belonging to their institution. Concerning the indirect correlation, a significant relationship is found in religiosity on organizational commitment through job satisfaction ( ${ }^{*}$ significant to a $5 \%$ ) because religiosity affects the employees' sense toward their job satisfaction. Moreover, the indirect correlation is considered higher than the direct relationship.

Similar to the previous study, it is concluded that religiosity has a significant effect on the employees' commitment and job satisfaction in the organization. A religiousoriented concept in the workplace is related to attitudes and beliefs about work behavior. Several studies have proven a strong correlation between employee religiosity and job attitudes, such as organizational commitment and dedication [11]. Furthermore, Wening and Choerudin [7] researched three dimensions of religiosity: belief, commitment, and behavior dimensions, organizational commitment, job satisfaction, and personal 
performance on education staff. The result showed that religiosity in the belief dimension has less influence on individual commitment in the organization.

This research is different from the previous study in terms of the correlation of religiosity toward employees' intention to stay. The finding of this research contradicts the report of [24], who found that religiosity had no significant effect on turnover intentions. Moreover, [22] also found that intrinsic religiosity was negatively related to turnover intention, and extrinsic religiosity was positively related to turnover intention. Both dimensions jointly influenced turnover intentions. Intrinsic religiosity contributed negatively to turnover intentions, while extrinsic religiosity contributed positively to the changes in turnover.

This research finds out that religiosity contributes positively to employees' intention to stay. Since religiosity has a significant correlation to predict intention to stay, the more religious they are, the higher the possibility they will stay. In contrast, the employees who keep religious beliefs in their workplace tend to perform outstandingly in their job. Moreover, this encouragement leads them to have a high level of commitment to the institution and think about the institution's future. As a result, religiosity is an excellent predictor of identifying the employees' intention to stay.

\section{Conclusion}

This research analyzes the turnover factors of employees' influencing intention to stay in Indonesian Islamic universities. Regarding the hypotheses, it can be concluded that religious beliefs influence job satisfaction. It shows that having religious feelings encourages the employee to have more commitment to contribute more. Job satisfaction significantly impacts the employees' commitment. Religiosity indirectly has a positive impact on organizational commitment through job satisfaction. Religiosity is positively related to employees' intention to stay. The study results were gained on limited and small samples. Hence, future studies need to use larger samples of respondents. Besides, further research needs to employ other factors to examine the effect of employees' intention to stay.

\section{References}

[1] S. E. Jackson and R. S. Schuler, "Understanding human resource management in the context of organizations and their environments," Annual review of psychology, vol. 46, pp. 237-264, 1995. https://doi.org/10.1146/annurev.ps.46.020195.001321.

[2] D. Dhanraj and S. B. Parumasur, "Perceptions of the impact of job rotation on employees, productivity, the organization and on job security," Corporate Ownership \& Control, vol. 11, pp. 682-691, 2014.

[3] J. B. Tracey and T. R. Hinkin, "Contextual Factors and Cost Profiles Associated with Employee Turnover," Cornell Hospitality Quarterly, vol. 49, pp. 12-27, 2008. https://doi.org/10.1177/0010880407310191.

[4] M. A. Abelson and B. D. Baysinger, "Optimal and Dysfunctional Turnover: Toward an Organizational Level Model," Academy of Management Review, vol. 9, pp. 331341, 1984. https://doi.org/10.5465/amr.1984.4277675.

[5] J. E. King and I. O. Williamson, "Workplace Religious Expression, Religiosity and Job Satisfaction: Clarifying a Relationship," Journal of Management, Spirituality \& Religion, vol. 2, pp. 173-198, 2005. https://doi.org/10.1080/14766080509518579.

[6] E. J. Kutcher, J. D. Bragger, O. Rodriguez-Srednicki, and J. L. Masco, "The Role of Religiosity in Stress, Job Attitudes, and Organizational Citizenship Behavior," 
Journal of Business Ethics, vol. 95, pp. 319-337, 2010. https://doi.org/10.1007/s10551-009-0362-z.

[7] N. Wening and A. Choerudin, "The influence of religiosity towards organizational commitment, job satisfaction and personal performance," Polish Journal of Management Studies, vol. 11, 2015.

[8] L. J. Williams and J. T. Hazer, "Antecedents and consequences of satisfaction and commitment in turnover models: A reanalysis using latent variable structural equation methods," Journal of applied psychology, vol. 71, p. 219, 1986. www.psycnet.apa.org/doi/10.1037/0021-9010.71.2.219.

[9] A. Cohen, "Antecedents of organizational commitment across occupational groups: A meta-analysis," Journal of Organizational Behavior, vol. 13, pp. 539-558, 1992. https://doi.org/10.1002/job.4030130602.

[10] N. Bouarif, "Predicting organizational commitment: The role of religiosity and ethical ideology," European Scientific Journal, vol. 11, 2015.

[11] E. Sikorska-Simmons, "Predictors of Organizational Commitment Among Staff in Assisted Living," The Gerontologist, vol. 45, pp. 196-205, 2005. https://doi.org/10.1093/geront/45.2.196.

[12] T. L. Davis, B. A. Kerr, and S. E. R. Kurpius, "Meaning, Purpose, and Religiosity in at-Risk Youth: The Relationship between Anxiety and Spirituality," Journal of Psychology and Theology, vol. 31, pp. 356-365, 2003. https://doi.org/10.1177/009164710303100406.

[13] O. Okpara John, "Personal characteristics as predictors of job satisfaction: An exploratory study of IT managers in a developing economy," Information Technology \&amp; People, vol. 17, pp. 327-338, 2004. https://doi.org/10.1108/09593840410554247.

[14] M. B. Frye, "Equity-Based Compensation for Employees: Firm Performance and Determinants," Journal of Financial Research, vol. 27, pp. 31-54, 2004. https://doi.org/10.1111/j.1475-6803.2004.00076.x.

[15] M. M. Parvin and M. N. Kabir, "Factors affecting employee job satisfaction of pharmaceutical sector," Australian journal of business and management research, vol. 1, p. 113, 2011.

[16] L. Firth, J. Mellor David, A. Moore Kathleen, and C. Loquet, "How can managers reduce employee intention to quit?," Journal of Managerial Psychology, vol. 19, pp. 170-187, 2004. https://doi.org/10.1108/02683940410526127.

[17] R. Gersten, T. Keating, P. Yovanoff, and M. K. Harniss, "Working in Special Education: Factors that Enhance Special Educators' Intent to Stay," Exceptional Children, vol. 67, pp. 549-567, 2001. https://doi.org/10.1177/001440290106700408.

[18] C.-S. Lee and C.-W. Chao, "Intention to "Leave" or "Stay" - The Role of Internship Organization in the Improvement of Hospitality Students' Industry Employment Intentions," Asia Pacific Journal of Tourism Research, vol. 18, pp. 749-765, 2013. https://doi.org/10.1080/10941665.2012.695290.

[19] M. Alausa Waheed, "Perceived Job Insecurity, Sex and Age as Predictors of Turnover Intentions among Employees of Merged Banks," 2012.

[20] W. H. Mobley, R. W. Griffeth, H. H. Hand, and B. M. Meglino, "Review and conceptual analysis of the employee turnover process," Psychological Bulletin, vol. 86, pp. 493-522, 1979. https://doi.org/10.1037/0033-2909.86.3.493.

[21] A. H. Khan and M. Aleem, "Impact of job satisfaction on employee turnover: An empirical study of Autonomous Medical Institutions of Pakistan," Journal of International Studies, vol. 7, pp. 122-132, 2014. https://doi.org/10.14254/20718330.2014/7-1/11. 
[22] E. I. Olowookere, O. A. Adekeye, G. O. Adejumo, B. C. Agoha, and M. A. Sholarin, "Influence of religiosity on turnover intention : empirical evidence from Sselected employees in Lagos and Ogun States," IFE PsychologIA : An International Journal, vol. 24, pp. 132-138, 2016. www.hdl.handle.net/10520/EJC-59aab8679.

[23] M. E. Malik and B. Naeem, "Role of spirituality in job satisfaction and organizational commitment among faculty of institutes of higher learning in Pakistan," African journal of business management, vol. 5, p. 1236, 2011. https://doi.org/10.5897/AJBM10.642.

[24] N. Hassan, A. Mohammad, F. Mohd, A. Rozilah, and S. Ali, "Religiosity perceptions and employee turnover intention in Malaysia," International Journal of Social Science and Humanity, vol. 5, pp. 120-125, 2015. https://doi.org/10.7763/IJSSH.2015.V5.436.

[25] J. Milliman, A. J. Czaplewski, and J. Ferguson, "Workplace spirituality and employee work attitudes: An exploratory empirical assessment," Journal of organizational change management, vol. 16, pp. 426-447, 2003. https://doi.org/10.1108/09534810310484172.

[26] I. Ghazzawi and Y. Smith, "Crafting the whole employee: Job satisfaction, job commitment, and faith-a new conceptual framework and research agenda," The business review, vol. 12, pp. 300-309, 2009.

[27] Z. O. Salem and S. O. S. Agil, "The effects of islamic individuals' ethics on organizational commitment of employees in Libyan public banks," British Journal of Arts and Social Sciences, vol. 9, pp. 64-78, 2012.

[28] Y. Kudo, T. Satoh, K. Hosoi, T. Miki, M. Watanabe, S. Kido, et al., "Association between Intention to Stay on the Job and Job Satisfaction among Japanese Nurses in Small and Medium-sized Private Hospitals," Journal of Occupational Health, vol. 48, pp. 504-513, 2006. https://doi.org/10.1539/joh.48.504.

[29] S. M. Azeem, "Job satisfaction and organizational commitment among employees in the Sultanate of Oman," 2010. https://doi.org/10.4236/psych.2010.14038.

[30] R. Zafar, M. Altaf, M. M. M. Bagram, and H. Hussain, "Religiosity, as determinant of turnover intention: An exploratory study," 2015.

[31] D. F. Birks and N. K. Malhotra, Marketing Research: an applied approach: Pearson Education UK, 2006. 